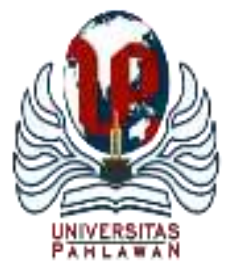

Edukatif : Jurnal Ilmu Pendidikan Volume 3 Nomor 6 Tahun 2021 Halm 5220 - 5230

EDUKATIF: JURNAL ILMU PENDIDIKAN

Research \& Learning in Education

https://edukatif.org/index.php/edukatif/index

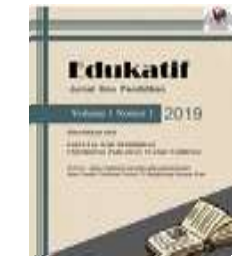

\title{
Pemanfaatan Model Project Based Learning Digital Storytelling untuk Meningkatkan Kepercayaan Diri Mahasiswa
}

\author{
Apdelmi $^{1 凶}$, Anny Wahyuni ${ }^{2}$, Reka Seprina ${ }^{3}$ \\ Universitas Jambi, Indonesia ${ }^{1,2,3}$ \\ E-mail : apdelmi.fkip@unja.ac.id ${ }^{1}, \underline{\text { anny123@unja.ac.id }}^{2}, \underline{\text { reka.seprina@unja.ac.id }}^{3}$
}

\begin{abstract}
Abstrak
Penelitian ini bertujuan untuk untuk meningkatkan kepercayaan diri mahasiswa kelas B prodi Pendidikan Sejarah pada mata kuliah sejarah Asia Tenggara. Penelitian ini merupakan Penelitian Tindakan Kelas (PTK) yang dilaksanakan dalam 3 siklus. Tiap siklus terdiri dari tahapan perencanaan, Implementasi Tindakan, Observasi dan Analisis dan Refleksi. Teknik pengumpulan data yang digunakan yaitu observasi, wawancara studi dokumentas dan studi literature. Hasil penelitian menunjukan bahwa Penggunakan Model Project Based Learning Digital Storyteling pada mata kuliah Sejarah Asia Tenggara di prodi pendidikan sejarah dapat diterapkan dengan baik dilihat dari skor rata pada siklus satu mendapat 43,33\%, pada siklus II mendapat skor sebanyak $70 \%$, artinya mengalami peningkatan sebanyak 26,67\%. Pada siklus III skor rata perolehan setiap kelompok adalah $90,55 \%$ itu artinya mengalami peningkatan sebanyak 20,55\%. Sedangkan untuk kepercayaan diri mengalami peningkatan siklus satu mendapat $40 \%$, pada siklus II mendapat $63 \%$ dan siklus III mendapat $86 \%$.
\end{abstract}

Kata Kunci: Digital, Storytelling, IGTV, Kepercayan Diri.

\section{Abstract}

This research aims to increase the confidence of students of class B history education program in Southeast Asian history courses. This research is a Class Action Research (PTK) conducted in 3 cycles. Each cycle consists of stages of planning, Implementation of Actions, Observation and Analysis and Reflection. Data collection techniques used are observation, document study interviews and literature studies. The results showed that the Use of Project Based Learning Digital Storyteling Model in Southeast Asian History courses in history education programs can be applied well from the average score in cycle one got $43.33 \%$, in cycle II got a score of $70 \%$, meaning an increase of $26.67 \%$. In cycle III the average score of each group is $90.55 \%$ which means an increase of $20.55 \%$. As for confidence experiencing an increase in cycle one gets $40 \%$, in cycle II gets $63 \%$ and cycle III gets $86 \%$.

Keywords: content, formatting, article.

Copyright (c) 2021 Apdelmi, Anny Wahyuni, Reka Seprina

$\triangle$ Corresponding author

Email : apdelmi.fkip@unja.ac.id

DOI : https://doi.org/10.31004/edukatif.v3i6.1689 


\section{PENDAHULUAN}

Kegiatan perkuliahan di lingkungan Universitas Jambi merupakan salah satu poin dari Tri Dharma Perguruan Tinggi yaitu aspek pendidikan dan pengajaran. Dalam aspek ini tugas dosen di prodi pendidikan sejarah bukan hanya sebatas transfer of knowledge tetapi hingga ranah transfer of value agar mahasiswa mampu tumbuh dan berkembang dengan baik termasuk aspek kepercayaan diri. Kepercayaan diri menurut hakim Dewi et al., (2013:10) merupakan keyakinan seseorang atas segala kelebihannya dalam segala aspek yang membuatnya merasa mampu untuk mencapai tujuan dalam hidupnya. Kepercayaan diri sangat penting dimilki oleh mahasiswa prodi pendidikan Sejarah Fakultas Keguruan dan Ilmu Pendidikan. Mahasiswa prodi pendidikan sejarah ini merupakan calon guru dimasa yang akan datang dituntut memiliki keterampilan baik dalam menguasai materi agar mudah di pahami siswa dan dituntut harus memiliki rasa percaya diri agar nantinya dapat mentranfer pembelajaran secara efektif kepada peserta didik.

Berdasarkan hasil pengamatan selama mengajar selama perkuliahan mahasiswa prodi pendidikan sejarah masih memiliki kepercayaan diri yang rendah di lihat dari sikap mereka yang suka mencontek, tidak mandiri, merasa dikucilkan dilingkungan akademis, cendrung pasif dalam perkuliahan dan iri ketika temannya mendapat nilai bagus tetapi dia tidaka berusaha maksimal dalam perkuliahan pernyatan ini perkuat dengan hasil penelitian yang dilakukan Ramadhani \& Putrianti, (2014:3) menjelaskan bahwa dari dari total 45 responden, $76 \%$ merasa jatungnya berdegup kencang saat berbicara di depan umum, $48 \%$ merasa jarinya berubah menjadi dingin, $85 \%$ mengalami kecemasan ketika berdialog, menjawab pertanyaan dan memberi pertanyaan di depan kelas. Dari data ini terlihat bahwa masiswa masih rendah tingkat kepercayaan dirinya.

Sikap yang ditunjukan oleh mahasiswa prodi pendidikan sejarah ini mengindikasikan bahwa rendahnya tingkat kepercayaan diri. Rendahnya kepercayaan diri mahasiswa prodi pendidikan sejarah ini bukanlah masalah yang sederhana, Dosen harus mengatasi permasalahan tersebut salah satu melalui model Project Based Learning Digtal Storytelling IGTV. Model Project Based learning merupakan model pembelajaran berbasis proyek dengan mencoba mengkaitkan antara teknologi dengan masalah sehari-hari mahasiswa (Nuraini et al., 2020:82). Adapun project yang akan digunakan dalam mengatasi permasalahan ini melalui storytelling yang dikemas dalam bentuk video nantinya akan di upload dalam media sosial. Kehadiran media sosial dan internet mempermudah pennguna untuk mendapatkan informasi maupun hiburan dari penjuru dunia tanpa terbatas jarak dan waktu. Media sosial merupakan medium internet yang memungkinkan pengguna merepresentasikan dirinya maupun berinteraksi, bekerjasama, berbagi, berkomunikasi dengan pengguna lain dan membentuk ikatan sosial secara virtual (Nasrullah, 2014:3).

Media sosial banyak jenisnya pada masa sekarang ada Facebook, Youtube, WhatsApp, Twitter, Line, Tiktok dan Instagram Didalam Instagram ini terdapat fitur yang bernama IGTV. IGTV ini merupakan tempat untuk mengaupload digital storytelling dengan durasi waktu yang cukup panjang. Alasan peneliti memilih Instagram memiliki fitus IGTV ini karena ketika peneliti melakukan wawancara dengan mahasiswa prodi pendidikan sejarah semua mahasiswa prodi pendidikan sejarah mempunyai intagram yang setiap hari mereka akses dan mereka gunakan hanya untuk upload foto kegiatan kegiatan mereka dan tidak pernah istagram mereka dimanfatkan untuk kepentingan perkuliahan. Padahal pendidikan masa kini berada pada revolusi digital yang telah mengubah cara pandang seseorang dalam menjalani kehidupan. Cara yang dapat dilakukan untuk mengembangkan media pembelajaran dengan memanfaatkan teknologi digital dalam bidang pendidikan berupa digital storytelling. Digital storytelling menurut robbin merupakan kombinasi dari seni bercerita dengan fitur multimedia yaitu grafik digital, taks rekaman narasi suara, video dan music menyajikan materi tertemtu dengan durasi waktu tertentu yang dikemas dalam format digital (Prananta et al., 2016:547).

Dgital storytelling ini sangat cocok digunakan untuk salah satu mata kuliah di prodi pendidikan sejarah yaitu Sejarah Asia Tenggara agar perkuliahan tidak mengalami kejenuhan. Dalam pembuatan digital storytelling ini mahasiswa akan melakukan kombinasi video, suara, gamba, teks dan raut wajah serta intonasi 
suara dalam menjelaskan materi terkait Mata kuliah Asia Tenggara sehingga materi tersampaikan dengan baik berdasarkan prinsp, konsep, kronologis waktunya. Digital storytelling merupakan salah satu alternatif yang dapat digunakan untuk mengelola konten internet. Digital storytelling bukan hanya memindahkan seni mendogeng ke dalam format multimedia yang berisi gambar, teks, suara serta video mengunakan aplikasi komputer. Digital storytelling memiliki elemen, tahaan serta tujuan edukasi yang merupakan sebuah strategi untuk meningktakan kepercayaan diri mahasiswa khususnya prodi pendidikan sejarah sebagai proses dari lifelong learning educaton.

Proyek digital storytelling ini melibatkan faktor emosional sehingga meningkatakn kepercayaan diri mahasasiswa dan daya ingat serta rasa ingin tahu bagi mahasiswa yang mendengarkannya. Permasalahan diatas ini menyebabkan peneliti tertarik untuk melakukan penelitian tindakan kelas dengan Judul "Pemanfaatan Model Project Based Learning Digital Storytelling IGTV untuk Meningkatkan Rasa Percaya Diri Mahasiswa pada Mata Kuliah Sejarah Asia Tenggara Prodi Pendidikan Sejarah. Penelitian ini memiliki kesamaan dengan judul penelitian kepercayaan diri dan komunikasi matematika melalui project based learning yaitu sama mengunakan model project based learning dan kepercayan diri tapi di penelitian saya mengkhususkan project ke digital storytelling. Penelitian ini juga bertujuan untuk mendeskripsikan peningkatan kepercayaan diri mahasiswa setelah diterapkannya model Project Based Learning Digital storytelling IGTV dan menjabarkan kendala serta solusi dalam kegiatan project based learning digital storytelling IGTV.

\section{METODE PENELITIAN}

Penelitian ini merupakan penelitian tindakan kelas dengan subjek penelitian kelas B pada mata kuliah Sejarah Asia Tenggara Prodi Pendidikan FKIP Universitas Jambi tahun akademik 2021/2020. Penelitian ini dilaksanakan sebanyak tiga siklus. Masing-masing siklus terdiri dari empat tahap kegiatan yaitu perencanaan, Implementasi Tindakan, Observasi dan Analisis dan Refleksi. Hasil refleksi ini akan menjadi dasar dalam merencanakan tindakan yang akan diterapkan untuk siklus selanjutnya. Sebagai tambahan dalam PTK akan dilihat juga hubungan antara Proyect Based Learning Digital Storytelling dan Kepercayaan diri Mahasiswa dengan mengunakan alat analisis statistic sederhana. Rumus yang digunakan adalah korelasi produk moment sebagai berikut:

$$
r_{x y=}=\frac{N \cdot \sum x y-\left(\sum x\right)\left(\sum y\right)}{\sqrt{\left[N \cdot \sum x^{2}-\left(\sum x\right)^{2}\right]\left[N \cdot \sum y^{2}-\left(\sum y\right)^{2}\right.}}
$$

Teknik Pengumpulan data dalam penelitian pertama, Observasi. Dalam penelitian ini peneliti mengunakan observasi partisipan dimana peneliti berperan sebagai dosen dan pengamat. Dimana dosen mengamati mahasiswa yang terlibat dalam perkuliahan. Kedua, Wawancara. Wawancara yang akan dilakukan dalam penelitian ini merupakan wawancara terstruktur dengan narasumber Dosen Penanggung Jawab Mata kuliah Pancasila di Prodi Pendidikan Sejarah dan Mahasiswa pendidikan sejarah kelas B. Ketiga Studi Dokumentasi dalam penelitian ini mengunakan sumber berita, foto yang akan digunakan dalam Digital Storytelling IGTV. Keempat, Studi Literatur yang diperlukan dalam penelitian ini adalah buku atau karya tulis yang berhubungan dengan kepercayaan diri. Kelima, Catatan lapangan merupakan cacatan tertulis tentang apa yang dilihat, didengar dialami dan dipikirkan dalam rangka pengumpulan data dan refleksi terhadap data dalam penelitian tindakan kelas ini. Catatan lapangan ini memudahakan peneliti untuk mengingat kejadian dalam proses perkuliahan selama penelitian.

Teknik Analisis data digunakan dalam penelitian ini meliputi teknik kualitatif dan kuantitatif. Teknik kualitatif digunakan untuk mendeskripsikan keterlaksanaan rencana tindakan, menggambarkan hambatan yang 
muncul selama proses perkuliahan. serta mendeskripsikan aktivitas Kepercayaan Diri mahasiswa selama Dalam Penyajian Materi perkuliahan Asia Tenggara dalam bentuk Digital Storytelling serta diskusi selama perkuliahan. adapun validasi data dalam pengumpulan data kualitatif menggunakan member check, ekspert opinion dan triagulasi. Teknik kuantitatif digunakan untuk mendeskripsikan tentang efektifitas dari perkuliahan yang meliputi Kepercayaan Diri Mahasiswa. Data kuantitatif akan di peroleh dari hasil penskoran penerapan metode Project Based Learning Digital Storytelling IGTV dan Kepercayaan Diri Mahasiswa. Data kemudian dihitung dan dituliskan dalam bentuk tabel serta diagram sehinggat akan terlihat perkembangan atau peningkatan kepercayaan diri mahasiswa.

\section{HASIL DAN PEMBAHASAN PENELITIAN}

\section{Data Hasil Penerapan Model Project Based Learning Digital Storytelling}

Data hasil belajar hasil Penerapan Model Project Based Learning Digital Storytelling selama tindakan mengamati aspek aspek pertama, pemilihan konsep dan video yang menarik. Kedua, menggunakan informasi sumber yang terpercaya, ketiga, mengumpulkan proyek tepat waktu. Keempat, kesesuaian materi dengan yang dibahas. Kelima, memahami topik yang dibahas dengan baik. Keenam tidak plagiarisme. Ketujuh, mengunakan bahasa yang mudah dipahami. Perolehan nilai hasil penerapan Project Based Learning Digital Storytelling akan dijelakan dibawah ini.

Tabel 1 Hasil Belajar Mahasiswa

\begin{tabular}{rlccc}
\hline \multicolumn{1}{l}{ No } & Nama Kelompok & Siklus I & Siklus II & Siklus III \\
\hline 1 & KELOMPOK 1 & 16 & 25 & 34 \\
\hline 2 & KELOMPOK 2 & 14 & 21 & 32 \\
\hline 3 & KELOMPOK 3 & 14 & 24 & 31 \\
\hline 4 & KELOMPOK 4 & 18 & 32 & 31 \\
\hline 5 & KELOMPOK 5 & 16 & 24 & 35 \\
\hline JUMLAH SKOR SISWA & \multicolumn{2}{c}{18} & 126 & 163 \\
\hline JUMLAH SKOR MAX & \multicolumn{5}{c}{180} \\
\hline RATA-RATA & 43,33 & 70 & 90,55 \\
\hline
\end{tabular}

Berdasarkan tabel 1 diatas kemudian digambarkan dalam bentuk diagram dibawah ini: 


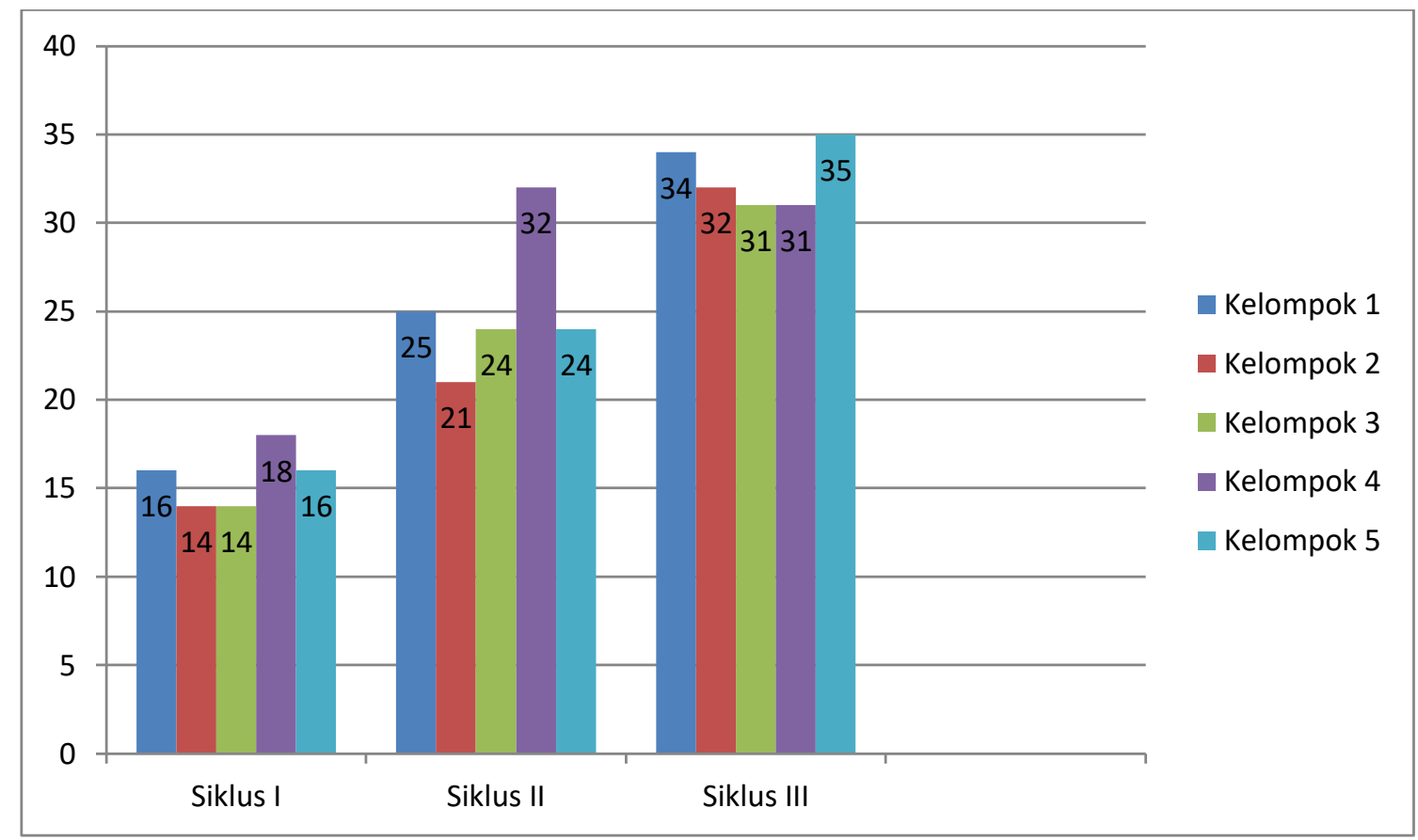

Gambar 1. Diagram Perolehan Skor Penerapan Model PjBL Digital Storytelling

Gambar 1. menunjukan hasil penilaian dari Model PjBL Digital Storytelling yang dilakukan oleh mahasiswa. Perolehan skor dalam Model PjBL Digital Storytelling menunjukan hasil yang memuaskan. Pada siklus I terlihat kelompok yang mendapat skor tinggi adalah kelompok 4, sednagkan skor terendah berada pada kelompok 3 dan 4 dengan perolehan skornya 14. Pada siklus II semua kelompok mengalami peningkatan. Kelompok 5 mengalam peningkatan yang tinggi dengan skor 32. Skor terendah adalah 21 di dapat oleh kelompok 2. Pada siklus III semua kelompok mengalami peningkatan kelompok yang mendapat nilai terendah adalah kelompok kelompok 3 dan 4. Dan skor tertinggi di raih oleh kelompok 5 dengan jumlah skor 35, selisih satu angka dengan kelompok 1 yang mendapat skor 34 .

Berdasarkan pernjelasan diatas secara umu disetiap siklus terlihat perolehan skor disetiap kelompok mengalami peningkatan dan penerapan Model Project Based Learning Digital Storytelling ini dapat dilaksanakan sangat baik dimasa pandemic dengan sistem kuliah online (daring) yang memanfaatkan aplikasi zoom metting. Data diatas dari hasil perolehan skor masing-masing kelompok dirata-ratakan. Adapun hasil rata-rata yang di peroleh tergambar pada diagram dibawah ini. 


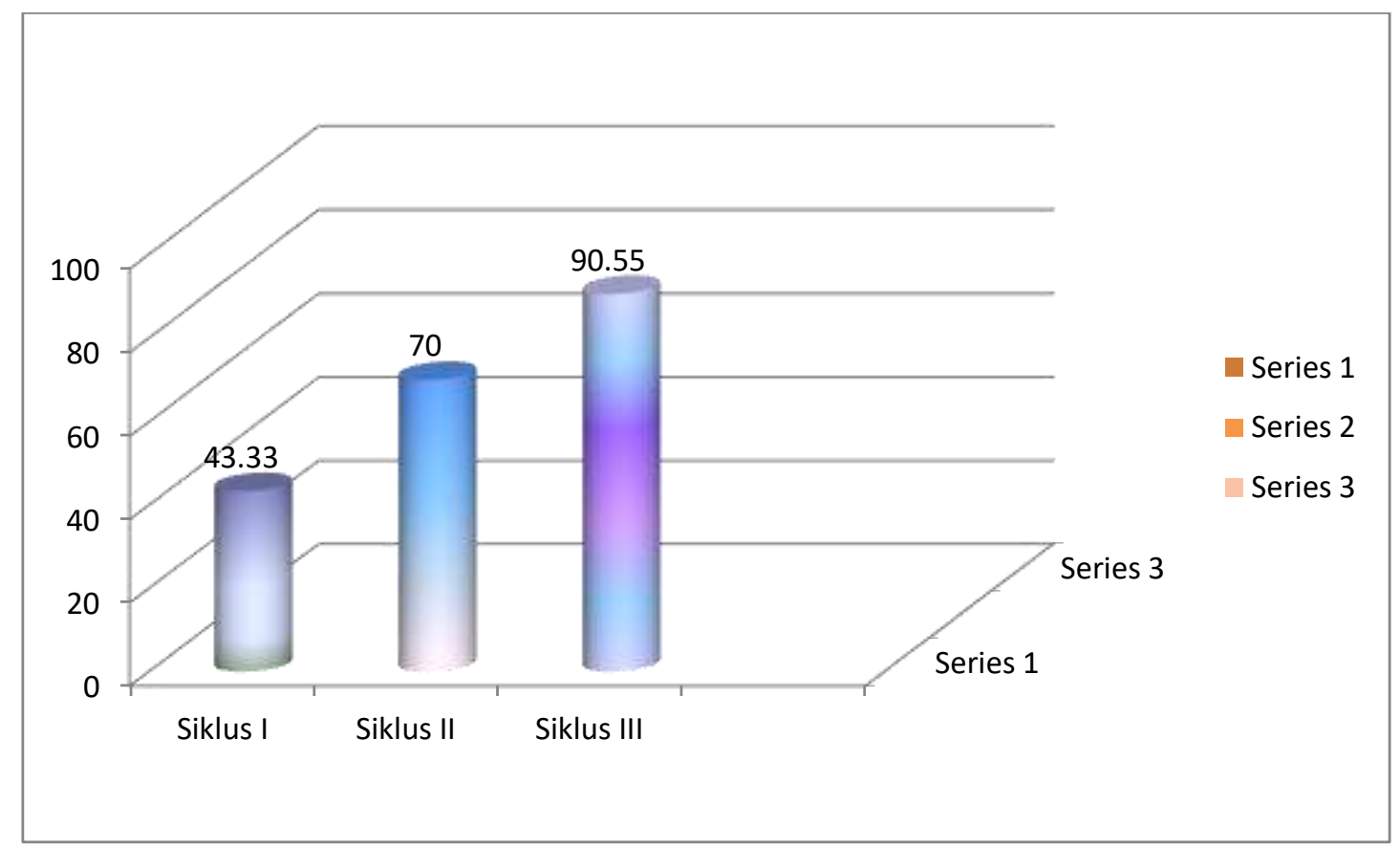

Gambar 2 Digram Perolehan Skor Rata-Rata Model PjBL Digital Storytelling Setiap Siklus

Diagram 2 diatas menunjukan terjadinya peningkatan perolehan skor yang didapatkan oleh setiap kelompok selama penerapan Model Project Based Learning Digital Strorytelling. Meskipun pada siklus I masih mendapat prediket cukup baik. Akan tetapi pada siklus II mendapat prediket baik dan siklus III mendapat prediket sangat baik. Skor rata pada siklus satu mendapat 43,33\%, kemudian pada siklus II mendapat skor sebanyak $70 \%$, artinya mengalami peningkatan sebanyak $26,67 \%$. Pada siklus III skor rata perolehan setiap kelompok adalah $90,55 \%$ itu artinya mengalami peningkatan sebanyak $20,55 \%$. Dengan demikian penerapan Model Project Based Learning Digital Stoorytelling dapat diterapkan dengan baik oleh dosen.

\section{Data Hasil Pengolahan Kepercayaan Diri mahasiswa}

Kepercayaan diri mahasiswa yang diamati selama pelaksanaan penelitian ini mencakup aspek aspek sebagai berikut: 1) Berani Mengemukakan pendapat, 2) tidak gegabah tetapi cepat mengambil keputusan, 3) Optimis, 4) Berani Tampil, 5) Berani mengemukakan pendapat, bertanya dan menjawab. dibawah ini akan dijelaskan perolehan skor dari kepercayaan diri mahasiswa.

Tabel.2. Pengamatan Kepercayaan Diri Mahasiswa

\begin{tabular}{|c|c|c|c|c|}
\hline No & Nama Kelompok & Siklus I & Siklus II & Siklus III \\
\hline 1 & KELOMPOK 1 & 15 & 25 & 34 \\
\hline 2 & KELOMPOK 2 & 14 & 21 & 32 \\
\hline 3 & KELOMPOK 3 & 13 & 24 & 32 \\
\hline 4 & KELOMPOK 4 & 21 & 29 & 35 \\
\hline 5 & KELOMPOK 5 & 17 & 27 & 39 \\
\hline \multicolumn{2}{|c|}{ JUMLAH SKOR SISWA } & 80 & 126 & 172 \\
\hline \multicolumn{2}{|c|}{ JUMLAH SKOR MAX } & \multicolumn{3}{|c|}{200} \\
\hline & RATA-RATA & 40 & 63 & 86 \\
\hline
\end{tabular}


5226 Pemanfaatan Model Project Based Learning Digital Storytelling untuk Meningkatkan Kepercayaan Diri Mahasiswa - Apdelmi, Anny Wahyuni, Reka Seprina

DOI: https://doi.org/10.31004/edukatif.v3i6.1689

Berdasarkan Tabel 2. kemudian digambarkan dalam bentuk diagram dibawah ini

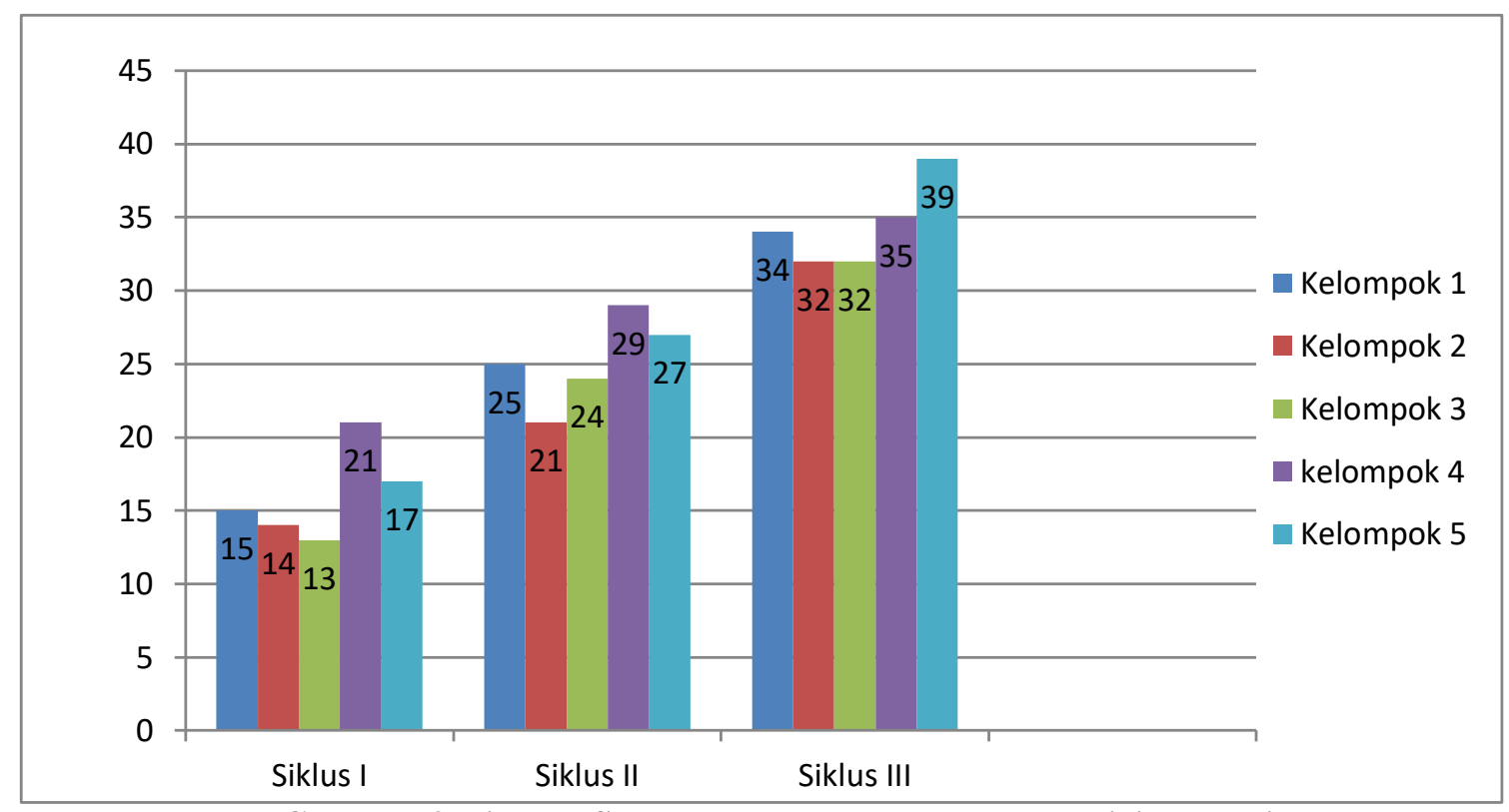

Gambar 3 Digram Skor Perolehan Kepercayaan Diri Mahasiswa

Berdasarkan diagram 3. diatas terlihat kepercayaan diri mahasiswa pendidikan sejarah pada mata kuliah sejarah Asia Tenggara sangat memuaskan semua kelompok mengalami peningkatan. Pada siklus I skor tertinggi di peroleh oleh kelompok 4 dengan skor 21. Pada siklus II semua kelompok mengalami peningkatan dalam perolehan skor kelompok satu dan kelompok 5 mengalami kenaikan yang signifikan. Sedangkan skor tertinggi diperoleh oleh. Pada siklus III terlihat setiap kelompok mengalami peningkatan dengan skor tertinggi 39 diperoleh oleh kelompok 5. Dengan demikian secara umum pada siklus III kepercayaan diri mahasiswa mengalami peningkatan. Dari perolehan skor di atas, maka skor tersebut diratakan, adapun hasil sebagai berikut:

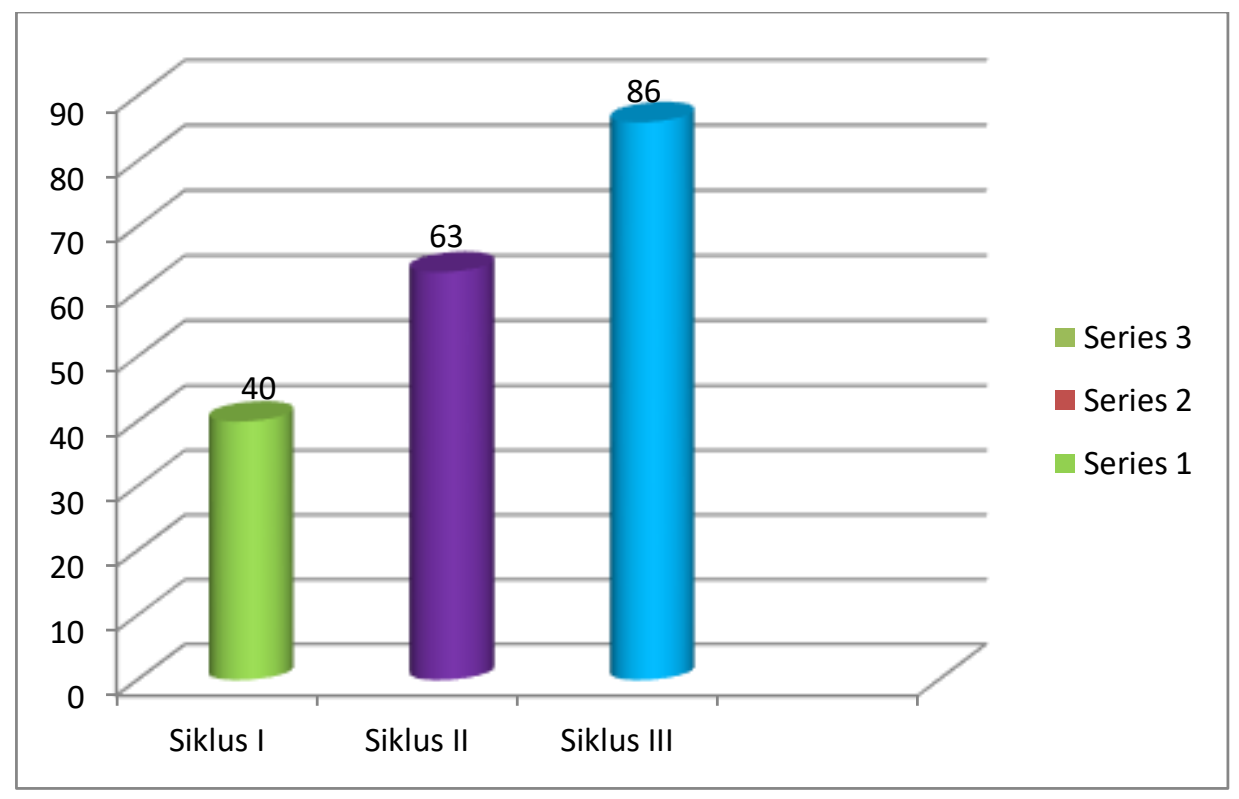

Gambar 4. Diagram Perolehan Skor Rata-Rata Kepercayaan Diri Mahasiswa di Setiap Siklus 
Berdasarkan diagram diatas terlihat jika setiap siklus kepercayaan diri mahasiswa mengalami peningkatan, meskipun pada siklus I nilai yang diperoleh mahasiswa masih tergolong rendah akan tetapi pada tingkat selanjutnya mengalami peningkatan yang sangat baik. Selanjutnya untuk mengetahui korelasi antara hasil penilaian individu dari digital storytelling dengan kepercayaan diri mahasiswa maka dengan menunakan rumus korelasi product moment seabagaimana sudah dikemukan pada bab III, maka dapa dihitung korelasi antara kemampuan berfikir kreatif dan kemampuan berfikir Kritis sebagai berikut:

Diketahui :

$$
\begin{array}{lc}
\mathrm{N}=28 & \sum \mathrm{X} . \mathrm{Y}=204.800 \\
\sum \mathrm{X}=2372 & \sum \mathrm{X}^{2}=201.126 \\
r_{x y}=\frac{N \mathrm{~N}=2418}{\sqrt{\left[N \cdot \sum \mathrm{Y}^{2}=209.048\right.}} \\
=\frac{28.204800-(2372)(2418)}{\sqrt{\left[28 \cdot 201.126-(2372)^{2}\right]\left[28 \cdot 209048-(2418)^{2}\right.}} \\
=\frac{1096}{\sqrt{(108.016)(112.324)}} \\
\mathrm{r}_{\mathrm{xy}}=0,995
\end{array}
$$

Jika nilai $\mathrm{r}$ dikonsultasikan dengan kriteria penafsiran korelasi maka korelasi antara hasil penilaian dari digital storyteliing per-individu mahasiswa dengan Kepercayaan Diri termasuk dalam kategori sangat tinggi dimana hubungan sangat baik. Digital storytelling merupakan suatu bentuk baru dari storytelling. Storttelling berarti mengekspresikan pengalaman, emosi dan ide dalam bentuk yang berbeda, strorytelling dapat membuat mahasiswa lebih peka terhadap sejarah, karena mereka dpaat mengalami sesuatu dengan mendengarkan, merasakan hal yang sama, mahasiswa mendapat sebuah bentuk rangkaian pengetahuan dan struktur cerita (Septiana, 2018:129). Stroyteling ini dibagi menjadi dua yaitu tradisional menampilkan tindakan heroic dan storytelling modern biasanya mengkombinasikan torsional dengan teknologi yang disebut Digital Storytelling.

Digital Storytelling dengan mengunakan aplikasi komputer, sebuah cerita yang diwujudkan dalam sebuah video yang dilengkapi dengan suara, gambar, teks dan animasi sehingga lebih menarik. Digital storytelling dalam perkuliahan merupakan salah satu metode pembelajaran yang mencoba mengabungkan beberapa keterampilan yaitu keterampilan mendegarkan, keterampilan berbicara, keterampilan menulis dan keterampilan mengoperasikan program yang memanfaatkan perkambangan komputer dan teknologi (Asri et al., 2017:81-82).

Digital Storytelling yang dibuat mahasiswa pendidikan sejarah dalam perkuliahan Asia Tenggara di upload di IGTV. IGTV Merupakan fitur yang ada di Instagram. IGTV ini dirilis tanggal 20 Juni 2018 di San Francisco (Amerika Serikat). IGTV merupakan fitus instagram yang mengizinkan pengguna mengupload video dengan durasi lebih panjanng dan dapat mencapai resoulusi $4 \mathrm{k}$. Dalam IGTV orang yang menontonnya bisa memberikan komentar langsung sehingga membuat mereka merasakan sedang menonton bersama sama dnegan peneonton lain (Datubara \& Irwansyah, 2019:256). IGTV salah satu solusi tempat untuk mengupload digital storytelling untuk meningkatkan kepercayaan mahasiswa prodi pendidikan sejarah.

Kepercayaan diri menurut Lie (Fkhrurrozi dan Wardi, 2020:1) adalah keyakinan akan kemampuan untuk menyelesaikan suatu pekerjaan dan masalah, dengan rasa percaya diri, seseorang dapat menyelesaikan tugas atau pekerjaan sesuai dengan tingkat perkembangannya dengan baik. Kepercayaan diri diri dipengaruhi oleh faktor orang tua dimana orang tua sangat berperan dalam mengembangkan kepercayaan diri seoarang anak. Anak merasa bernilai dan berharga bagi orang tua nya cendrung memiliki kepercayaan diri yang tinggi. faktor lain yang mempengaruhi kepercayaan diri adalah lingkungan lembaga pendidikan formal, dosen 
memiliki tugas penting untuk membentuk rasa percaya diri mahasiswa, dosen harus bisa menanamkan kepada mahasiswa untuk bangga dengan kemampuan dirinya sendiri karena setiap manusia itu memilikikarakteristik yang tidaklah sama. Lingkungan masyarakat merupakan faktor yang mempengaruhi keprcayaan diri, ketika mahasiswa itu sulit beirnteraksi dengan masyarakat barat dia memiliki kepercayaan diri yang rendah.

Kepercayaan diri tidak terbentuk dengan instan akan tetapi butuh proses dan keberanian dalam proses belajar disetiap kondisi yang dihadapi oleh mahasiswa. Kepercayaan diri memiliki indikator 1) berani mengutarakan pendapat, 2) tidak gegabah tapi bisa mengambl keputusan dengan cepat, 3) optimis, 4) berani tampil didepan banyak orang, 5) berani mengemukan pendapat, bertanya dna menjawab (Mukti, 2016:10). Mahasiswa yang memiliki kepercayaan diri yang tinggi sikap cendrung tenang tidak mudah takut serta berani tampil di perkuliahan dalam bentuk memberikan pertanyaan, menjawab pertanyaan dan menjelaskan materi kelompok.

\section{Kendala dihadapi Mahasiswa dalam pembuatan Digital Storytelling}

Digital storytelling ini memiliki manfaat berdasarkan standar Teknologi Pendidikan Nasional (NETS) yaitu keativitas dan inovasi, komunikasi dan kolaborasi, penelitian dan kelancaran informasi, berfikir kritis, pemecahan masalah, pengambilan keputuan, membangun kepercayaan diri, terwujudnya masyarakat digital dan pengoperasian teknologi dan konsep (Anggadewi, 2017:237). Digital storytelling ini memiliki beberapa kelebihan yaitu:

a. Bagi dosen menarik untuk digunakan dalam beragam gaya perkuliahan, membangkitkan minat mahasiswa, perhatian dan dan motivasi dalam perkuliahan. pembuatan Digital Storytelling bermodalkan pada bakat kreativitas mahasiswa. Digital Storyteling sebagai alat untuk menciptakan generasi yang kreatif dan alat yang digunakan untuk meningkatkan kepercayaan diri Mahasiswa.

b. Bagi mahasiswa digital storytelling ini memiliki kelebihan siswa dapat menegmbangkan kemampuan komunikasi, keterampilan menjalankan komputer dan meningkatkan keterampilan yang lain berkaitan dengan teknologi.

Kelemahan dari digital storytelling ini yaitu perlu penguasaan komputer dan perlu memperhatikan kecepatan ucapan, pilihan kata, kelancara, penguasan topic, penempatan tekanan, music backsound dan penggunaan gambar. Digital storytelling memiliki beberapa elemen penting yang dapat menjadi acuan dalam penilaian pertama, tujuan keseluruhan cerita kedua, sudut pandang narrator, ketiga, pertanyaan dramatis, keempat pilihan konten, kelima kejelasan suara, keenam, tahapan narasi, ketujuh, soundtrack sesuai dengan materi, kedelapan, kualitas gambar, kesembilan penggunaan tata bahasa (Yuliana \& Wantoro, 2017:553). Langkah langkah dalam perkuliahan dalam menerapkan Digital Storytelling diawali dengan menulis cerita atau materi, mengarang storyboard, mengembangkan digital storytelling dan menampilkan stroyteling di ruang pekuliahan.

\section{KESIMPULAN}

Berdasarkan hasil penelitian tindakan kelas Pemanfaatan Model Project Based Learning (PjBL) Digital Storytelling IGTV untuk Meningkatkan Kepercayaan Diri Mahasiswa pada Mata Kuliah sejarah Asia Tenggara Prodi Pendidikan Sejarah, penggunakan Model Project Based Learning Digital Storyteling pada mata kuliah Sejarah Asia Tenggara di prodi pendidikan sejarah dapat diterapkan dengan baik mengalami peningkatan dari setiap siklus dilihat dari skor rata pada siklus satu mendapat 43,33\%, pada siklus II mendapat skor sebanyak $70 \%$, artinya mengalami peningkatan sebanyak $26,67 \%$. Pada siklus III skor rata perolehan setiap kelompok adalah $90,55 \%$ itu artinya mengalami peningkatan sebanyak $20,55 \%$. Sedangkan untuk kepercayaan diri mengalami peningkatan siklus satu mendapat $40 \%$, pada siklus II mendapat $63 \%$ dan siklus 
5229 Pemanfaatan Model Project Based Learning Digital Storytelling untuk Meningkatkan Kepercayaan Diri Mahasiswa - Apdelmi, Anny Wahyuni, Reka Seprina

DOI: https://doi.org/10.31004/edukatif.v3i6.1689

III mendapat $86 \%$. Kendala yang ditemukan dalam penelitian ini mahasiswa belum terbiasa membuat video digital ini

\section{DAFTAR PUSTAKA}

Anggadewi, B. E. T. (2017). Digital Storytelling Sebagai Media Bagi Guru Untuk Mengembangkan Komunikasi Anak Berkebutuhan Khusus. Prosiding Temu Ilmiah X Ikatan Psikologi Perkembangan Indonesia, 1. Http://Jurnal.Unissula.Ac.Id/Index.Php/Ippi/Article/View/2194

Ardari, C. S. S. (2016). Pengaruh Kepercayaan Diri Terhadap Intensitas Penggunaan Media Sosial Pada Remaja Awal [Universitas Sanata Dharma Yogyakarta]. In Skripsi. Http://Repository.Usd.Ac.Id/Id/Eprint/6571

Asri, A. N., Indrianti, T., \& Perdanasari, N. (2017). Penerapan Digital Storytelling Dalam Pembelajaran Bahasa Inggris Di Program Studi Manajemen Informatika. Jurnal Ilmiah Edukasi \& Sosial, 8(2), 81-89. Https://Jiesjournal.Com/Index.Php/Jies/Article/View/90

Bukhori, B. (2016). Kecemasan Berbicara Di Depan Umum Ditinjau Dari Kepercayaan Diri Dan Keaktifan Dalam Organisasi Kemahasiswaan. Jurnal Komunikasi Islam, 6(1), 158-186.

Datubara, B. M., \& Irwansyah. (2019). Instagram TV: Konvergensi Penyiaran Digital Dan Media Sosial. Mediator: Jurnal Komunikasi, 12(2), 251-263. Https://Doi.Org/10.29313/Mediator.V12i2.4778

Dewi, D. M., Supriyo, \& Suharso. (2013). Kepercayaan Diri Ditinjau Dari Pola Asuh Orang Tua Pada Siswa Kelas VII (Studi Kasus). Indonesian Journal of Guidance And Counseling, 2(4), 9-16. Https://Doi.Org/10.15294/IJGC.V2I2.3189

Drajat, H., \& Purnama, H. (2020). Efektivitas Penggunaan Digital Storytelling Kanal Youtube “ Kok Bisa?" Dalam Meningkatkan Minat Belajar. Jurnal Komunikasi Universitas Garut, 6(1), 382-390. Https://Journal.Uniga.Ac.Id/Index.Php/JK/Article/View/815/693

Krisnawati, E., \& Julianingsih, D. (2019). Efektivitas Penggunaan Video Digital Storytelling Pada Materi Trigonometri Di Kelas X Untuk Meningkatkan Motivasi Belajar Siswa. JP3M (Jurnal Penelitian Pendidikan ..., 5(2), 55-62. Https://Doi.Org/10.37058/Jp3m.V5i2.888

Kristanti, Y., Subiki, \& Handayani, R. D. (2016). Model Pembelajaran Berbasis Proyek (Project Based Learning Model) Pada Pembelajaran Fisika Di SMA. Jurnal Pembelajaran Fisika Universitas Jember, 5(2), 122-128. Https://Jurnal.Unej.Ac.Id/Index.Php/JPF/Article/View/3958

Mirhan, J. B. K. J. (2016). Hubungan Antara Percaya Diri Dan Kerja Keras Dalam Olahraga Dan Keterampilan Hidup. Jurnal Olahraga Prestasi, $12(1), \quad 86-96$. Https://Doi.Org/10.21831/Jorpres.V12i1.9499

Mukti, K. (2016). Analisis Tingkat Kepercayaan Diri Peserta Didik Pogram Linta Minat Pada Mata Pelajaran Ekonomi Di SMA Negeri 14 Pealembang. In Skripsi. Universitas Muhamadiyah Purwokerto.

Nasrullah, R. (2014). Teori Dan Riset Media Siber (Cybermedia). Jakarta: Kencana Prenadamedia Group.

Nuraini, R., Febrianti, N., Fatmawati, E. B., \& Hartini, S. (2020). Penerapan Model Pembelajaran Daring Berbasis Proyek Untuk Meningkatkan Rasa Percaya Diri Peserta Didik Kelas I SD Negeri Redjodani. Prosiding Pendidikan Profesi Guru, 81-91.

Prabawardani, K., Agung, A. A. G., \& Parmiti, D. P. (2018). Pengaruh Metode Storytelling Berbantuan Komik Terhadap Keterampilan Berbicara Bahasa Indonesia Siswa Kelas V. Jurnal EDUTECH Universitas Pedidikan Ganesha, 6(2), 147-158. Https://Doi.Org/10.23887/Jeu.V6i2.20281

Prananta, Y. R., Setyosari, P., \& Santoso, A. (2016). Pemafaatan Digital Storytelling Sebagai Media Pembelajaran Tematik Di SD. Prosiding: Inovasi Pendidikan Di Era Big Data Dan Apek Psikologi.

Prihatiningsih, W. (2017). Motif Penggunaan Media Sosial Instagram Di Kalangan Remaja. Communication, 
5230 Pemanfaatan Model Project Based Learning Digital Storytelling untuk Meningkatkan Kepercayaan Diri Mahasiswa - Apdelmi, Anny Wahyuni, Reka Seprina

DOI: https://doi.org/10.31004/edukatif.v3i6.1689

8(1), 51. Https://Doi.Org/10.36080/Comm.V8i1.651

Rahmah, N. A. (2018). Pengaruh Penggunaan Fitur IGTV Terhap Eksistesi Diri Kalangan Mahasiswa Universitas Sumatra Utara [Universitas Sumatra Utara]. In Skripsi. Http://Repositori.Usu.Ac.Id/Handle/123456789/10875

Ramadhani, T. N., \& Putrianti, F. G. (2014). Hubungan Antara Kepercayaan Diri Dengan Citra Diri Pada Remaja Akhir. Jurnal Spirits, 4(2), 22. Https://Doi.Org/10.30738/Spirits.V4i2.1117

Sani, R. A. (2013). Inovasi Pembelajaran. Jakarta: Bumi Aksara.

Septiana, N. Z. (2018). Digital Storytelling Untuk Mengembangkan Aspek Spiritual Anak Taman KanakKanak (TK) Al Hidayah Bakung 01 Kabupaten Blitar. Realita: Jurnal Penelitian Dan Kebudayaan Islam, 16(2). Https://Doi.Org/10.30762/Realita.V16i2.1035

Sugiyono. (2019). Metode Penelitian Pendidikan. Bandung: Alfabeta.

Susanto, E., \& Susanta, A. (2020). Peningkatan Kepercayaan Diri Mahasiswa Dalam Pembelajaran Statiska Dasar Melalui Problem Based Learning. Jurnal The Original Of Mathematics, 4(2), 179-184. Http://Jurnal.Unma.Ac.Id/Index.Php/Th

Trianto. (2014). Mendesain Model Pembelajaran Inovatif, Progresif Dan Kontekstual. Jakarta: Pramedia Gramedia.

Yuliana, I., \& Wantoro, J. (2017). Berkreasi Dengan Digital Storytelling Sebagai Alternatif Strategi Pembelajaran. Seminas Nasional Kedua Pendidikan Berkemajuan Dan Mengembirakan. Http://Hdl.Handle.Net/11617/9573 